\title{
GEOSTATISTICS BANFF 2004
}

Volume 1 
Quantitative Geology and Geostatistics

VOLUME 14/1

The titles published in this series are listed at the end of this volume. 


\section{GEOSTATISTICS BANFF 2004}

\section{Volume 1}

\section{Edited by}

OY LEUANGTHONG

University of Alberta,

Edmonton, Canada

and

CLAYTON V. DEUTSCH

University of Alberta,

Edmonton, Canada

\section{黛 Springer}


A C.I.P. Catalogue record for this book is available from the Library of Congress.

ISBN-10 1-4020-3515-2 (HB) (indivisible set)

ISBN-13 978-1-4020-3515-9 (HB) (indivisible set)

ISBN-10 1-4020-3610-8 (e-book)

ISBN-13 978-1-4020-3610-1 (e-book)

Published by Springer,

P.O. Box 17, 3300 AA Dordrecht, The Netherlands.

www.springeronline.com

Printed on acid-free paper

All Rights Reserved

(C) 2005 Springer

No part of this work may be reproduced, stored in a retrieval system, or transmitted in any form or by any means, electronic, mechanical, photocopying, microfilming, recording or otherwise, without written permission from the Publisher, with the exception of any material supplied specifically for the purpose of being entered and executed on a computer system, for exclusive use by the purchaser of the work.

Printed in the Netherlands. 


\section{TABLE OF CONTENTS}

\section{VOLUME 1}

Foreword $\ldots \ldots \ldots \ldots$

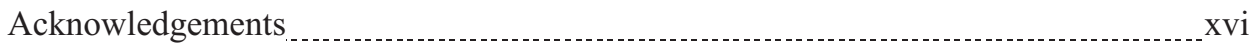

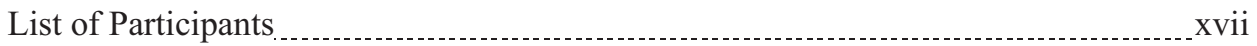

\section{PLENARY}

Accounting for Geological Boundaries in Geostatical Modeling of Multiple Rock Types

P. Larrondo and C.V. Deutsch

Data Integration using the Probability Perturbation Method

J. Caers

Spectral Component Geologic Modeling: A New Technology for Integrating

Seismic Information at the Correct Scale

T. Yao, C. Calvert, G. Bishop, T. Jones, Y. Ma and L. Foreman

Joint Simulations, Optimal Drillhole Spacing and the Role of the Stockpile

A. Boucher, R. Dimitrakopoulos and J. A. Vargas-Guzmán.

Theory of the Cloud Transform for Applications

$O$. Kolbjørnsen and P. Abrahamsen

Probability Field Simulation: A Retrospective

R. M. Srivastava and R. Froidevaux

Sequential Spatial Simulation Using Latin Hypercube Sampling

P. C. Kyriakidis

Field Scale Stochastic Modeling of Fracture Networks: Combining Pattern Statistics with Geomechanical Criteria for Fracture Growth

$X$. Liu and S. Srinivasan

Direct Geostatistical Simulation on Unstructured Grids J. Manchuk, O. Leuangthong and C. V. Deutsch. 
Directional Metropolis: Hastings Updates for Posteriors with Nonlinear Likelihoods

Detection of Local Anomalies in High Resolution Hyperspectral Imagery using Geostatistical Filtering and Local Spatial Statistics

P. Goovaerts

Covariance Models with Spectral Additive Components

D. Marcotte and M. Powojowski

A Statistical Technique for Modelling Non-stationary Spatial Processes

J. Stephenson, C. Holmes, K. Gallagher and A. Pintore

Conditioning Event-based Fluvial Models

M. J. Pyrcz and C. V. Deutsch.

3D Geological Modelling and Uncertainty: The Potential-field Method

C. Aug, J.-P. Chilès, G. Courrioux and C. Lajaunie.

Accounting for Non-stationarity and Interactions in Object Simulation for

Reservoir Heterogeneity Characterization

D. Allard, R. Froidevaux and P. Biver

Estimating the Trace Length Distribution of Fractures from Line Sampling Data

C. Lantuéjoul, H. Beucher, J.P. Chilès, C. Lajaunie and

H. Wackernagel

On Some Controversial Issues of Geostatistical Simulation

L. Y. Hu and M. Le. Ravalec-Dupin

On the Automatic Inference and Modelling of a Set of Indicator Covariances and Cross-Covariances

E. Pardo-Igúzquiza and P. A. Dowd.

On Simplifications of Cokriging

J. Rivoirard

Efficient Simulation Techniques for Uncertainty Quantification on Continuous Variables: A Process Preserving the Bounds, including Uncertainty on Data, Uncertainty on Average, and Local Uncertainty

P. Biver

Higher Order Models using Entropy, Markov Random Fields and Sequential Simulation

C. Daly 
Beyond Covariance: The Advent of Multiple-Point Geostatistics A. G. Journel

Non-Stationary Multiple-point Geostatistical Models

S. Strebelle and T. Zhang.

A Workflow for Multiple-point Geostatistical Simulation

Y. Liu, A. Harding, R. Gilbert and A. Journel

A Multiple-scale, Pattern-based Approach to Sequential Simulation

G. B. Arpat and J. Caers

Sequential Conditional Simulation Using Classification of

Local Training Patterns

T. Zhang, P. Switzer and A. Journel

A Parallel Scheme for Multi-scale Data Integration

$O$. I. Tureyen and J. Caers

Stochastic Modeling of Natural Fractured Media: A Review

J. P. Chilès

Geostatistical Simulation of Fracture Networks

R. M. Srivastava, P. Frykman and M. Jensen

The Promises and Pitfalls of Direct Simulation

O. Leuangthong

Sample Optimization and Confidence Assessment of Marine Diamond Deposits using Cox Simulations

G. Brown, C. Lantuéjoul and C. Prins

Inverse Conditional Simulation of Relative Permeabilities

J. Gómez-Hernández and C. Guardiola-Albert

Quantifiable Mineral Resource Classification: A Logical Approach

C. Dohm

\section{MINING}

Geostatistics in Resource/Reserve Estimation: A Survey of the Canadian Mining Industry Practice

M. Dagbert

Integration of Conventional and Downhole Geophysical Data in Metalliferous

Mines

M. Kay, R. Dimitrakopoulos and P. Fullagar 
The Kriging Oxymoron: A Conditionally Unbiased and Accurate Predictor ( $2^{\text {nd }}$ Edition)

E. Isaaks 363

Post Processing of SK Estimators and Simulations for Assessment of

Recoverable Resources and Reserves for South African Gold Mines

D. G. Krige, W. Assibey-Bonsu and L. Tolmay

The Practice of Sequential Gaussian Simulation

M. Nowak and G. Verly

Spatial Characterization of Limestone and Marl Quality in a Quarry for Cement

Manufacturing

J. A. Almeida, M. Rocha and A. Teixeira

A Non-linear GPR Tomographic Inversion Algorithm Based on Iterated

Cokriging and Conditional Simulations

E. Gloaguen, D. Marcotte and M. Chouteau

Application of Conditional Simulation to Quantify Uncertainty and to Classify

a Diamond Deflation Deposit

S. Duggan and R. Dimitrakopoulos

Geostatistical Simulation Techniques Applied to Kimberlite Orebodies and Risk Assessment of Sampling Strategies

J. Deraisme and D. Farrow

Modelling 3D Grade Distributions on the Tarkwa Paleoplacer Gold Deposit, Ghana, Africa

T. R. Fisher, K. Dagdelen and A. K. Turner

Conditional Simulation of Grade in a Multi-element Massive Sulphide Deposit N. A. Schofield

The Ultimate Test - Using Production Reality. A Gold Case Study

P. Blackney, C. Standing and V. Snowden

Ore-Thickness and Nickel Grade Resource Confidence at the Koniambo Nickel Laterite (A Conditional Simulation Voyage of Discovery)

M. Murphy, H. Parker, A. Ross and M.-A. Audet

Mineral Resource Classification Through Conditional Simulation

T.M. Wawruch and J.F. Betzhold

Geostatistical Investigation of Elemental Enrichment in Hydrothermal Mineral Deposits

A. R. Samal, R. H. Fifarek, and R. R. Sengupta 
Valuing a Mine as a Portfolio of European Call Options: The Effect of Geological Uncertainty and Implications for Strategic Planning

E. Henry, D. Marcotte, and M. Samis 501

Classification of Mining Reserves using Direct Sequential Simulation

A. Soares

Using Unfolding to Obtain Improved Estimates in the Murrin Murrin Nickel-

cobalt Laterite Deposit in Western Australia

M. Murphy, L. Bloom, and U. Mueller

Measures of Uncertainty for Resource Classification

L. Eduardo de Souza, J.F.C.L. Costa, and J.C. Koppe

Incorporating Uncertainty in Coal Seam Depth Determination via Seismic

Reflection and Geostatistics

V. C.Koppe, F. Gambin, J.F.C.L. Costa, J.C. Koppe,

G. Fallon, and N. Davies

Implementation Aspects of Sequential Simulation

S. Zanon and $O$. Leuangthong.

\section{VOLUME 2}

\section{PETROLEUM}

Early Uncertainty Assessment: Application to a Hydrocarbon Reservoir

Appraisal

G. Caumon and A. G. Journel

Reservoir Facies Modelling: New Advances in MPS

A. Harding, S. Strebelle, M. Levy, J. Thorne, D. Xie, S. Leigh, R. Preece and R. Scamman.

Fitting the Boolean Parameters in a Non-stationary Case

H. Beucher, M. B. García-Morales and F. Geffroy.

Fine Scale Rock Properties: Towards the Spatial Modeling of Regionalized

Probability Distribution Functions

M. García, D. Allard, D. Foulon and S. Delisle

A Combined Geostatistical and Source Model to Predict Superpermeability from Flowmeter Data: Application to the Ghawar Field J. Voelker and J. Caers

Combining Methods for Subsurface Prediction

P. Abrahamsen 
Process-based Reservoir Modelling in the Example of Meandering Channel

I. Cojan, O. Fouché, S. Lopéz and J. Rivoirard.

Multiple Point Geostatistics: Optimal Template Selection and Implementation

in Multi-Threaded Computational Environments

A. E. Barrera, J. Ni, and S. Srinivasan

Direct Assessment of Uncertainty using Stochastic Flow Simulation

J. Y. Leung and S. Srinivasan

Preservation of Multiple Point Structure when Conditioning by Kriging

W. Ren, L. B. Cunha and C. V. Deutsch.

Stochastic Modeling of the Rhine-Meuse Delta using Mutiple-point

Geostatistics

A. Maharaja

Stochastic Simulation of Undiscovered Petroleum Accumulations

Z. Chen, K. G. Osadetz and H. Gao

Prediction of Spatial Patterns of Saturation Time-lapse from Time-lapse

Seismic

J. Wu, T. Mukerji and A. Journel.

Statistical Scale-up: Concepts and Application to Reservoir Flow Simulation Practice

L. W. Lake, S. Srinivasan and A. John

Coupling Sequential-Self Calibration and Genetic Algorithms to Integrate

Production Data in Geostatistical Reservoir Modeling

X. H. Wen, T. Yu, and S. Lee

High Resolution Geostatistics on Coarse Unstructured Flow Grids

G. Caumon, O. Grosse, and J. L. Mallet

Assessment of Uncertainty in Reservoir Production Forecasts Using Upscaled Flow Models

O.P. Lødøen, H. Omre, L.J. Durlofsky, and Y. Chen

Sensitivity of Oil Production to Petrophysical Heterogeneities

A. Skorstad, O. Kolbjørnsen, B. Fjellvoll, J. Howell, T. Manzocchi, and

J.N. Carter

Scaling Relations and Sampling Volume for Seismic Data

P. Frykman, O.V. Vejboek, and R. Rasmussen.

Hidden Markov Chains for Identifying Geological Features from Seismic Data

J. Eidsvik, E. Gonzalez, and T. Mukerji 
Evaluation of Stochastic Earth Model Workflows, Vertical Up-Scaling and Areal Up-scaling Using Data from the Eunice Monument South Unit (New Mexico) and the LL-652 Central Fault Block (Venezuela) Reservoirs W.S. Meddaugh

Application of Design of Experiments to Expedite Probabilistic Assessment of Reservoir Hydrocarbon Volumes (OOIP)

Stochastic Reservoir Model for the First Eocene Reservoir, Wafra Field, Partitioned Neutral Zone (PNZ)

W.S. Meddaugh, D. Dull, S.D. Griest, P. Montgomery, and G. McNaboe. 757

Multiple-point Statistics to Generate Pore Space Images

H. Okabe and M.J. Blunt

Local Updating of Reservoir Properties for Production Data Integration

L. Zhang, L.B. Cunha, and C.V. Deutsch

\section{ENVIRONMENTAL}

Comparison of Model Based Geostatistical Methods in Ecology: Application to Fin Whale Spatial Distribution in Northwestern Mediterranean Sea P. Monestiez, L. Dubroca, E. Bonnin, J. P. Durbec and C. Guinet

Simulation-based Assessment of a Geostatistical Approach for Estimation and Mapping of the Risk of Cancer

P. Goovaerts

Air Quality Assessment using Stochastic Simulation and Neural Networks

A. Russo, C. Nunes, A. Bio, J. Pereira and A. Soares

Mapping Land Cover Changes with Landsat Imagery and Spatio-temporal Geostatistics

A. Boucher, K. Seto and A. Journel

Spherical Wavelets and their Application to Meteorological Data

H. S. Oh

Multivariate Geostatistical Mapping of Atmospheric Deposition in France

O. Jaquet, L. Croisé, E. Ulrich and P. Duplat

Geostatistical and Fourier Analysis Applied to Cross-hole Tomography

Seismic Data

J. M. Carvalho and A. T. Cavalheiro 
The Importance of De-clustering and Uncertainty in Climate Data: A Case Study of West African Sahel Rainfall

A. Chappell and M. Ekström.

S. GeMS: The Stanford Geostatistical Modelling Software: A Tool for New Algorithms Development

N. Remy

Evaluating Techniques for Multivariate Classification of Non-collocated Spatial

Data

S. A. McKenna

Travel Time Simulation of Radionuclides in a 200 m Deep Heterogeneous Clay

Formation Locally Disturbed by Excavation

M. Huysmans, A. Berckmans and A. Dassargues

Geostatistics and Sequential Data Assimilation

H. Wackernagel and L. Bertino

Spatial Properties of Seasonal Rainfall in Southeast England

M. Ekström and A. Chappell

Geostatistic Indicators of Waterway Quality for Nutrients

C. Bernard-Michel and C. de Fouquet

Application of Geostatistical Simulation to Enhance Satellite Image Products

C. A. Hlavka and J. L. Dungan

Geostatistical Noise Filtering of Geophysical Images: Application to

Unexploded Ordnance (UXO) Sites

H. Saito, T. C. Coburn, and S. A. McKenna

\section{THEORY \& SELECTED TOPICS}

Modeling Skewness in Spatial Data Analyis without Data Transformation

P. Naveau and D. Allard

Gradual Deformation of Boolean Simulations

M. Le Ravalec-Dupin and L. Y. Hu

When can Shape and Scale Parameters of a 3D Variogram be Estimated?

P. Dahle, O. Kolbjørnsen and P. Abrahamsen

Comparison of Stochastic Simulation Algorithms in Mapping Spaces of Uncertainty of Non-linear Transfer Functions

S. E. Qureshi and R. Dimitrakopoulos 
Integrating Multiple-point Statistics into Sequential Simulation Algorithms J. M. Ortiz and X. Emery.

Post-processing of Multiple-point Geostatistical Models to Improve

Reproduction of Training Patterns

S. Strebelle and N. Remy

Improving the Efficiency of the Sequential Simulation Algorithm using Latin Hypercube Sampling

G. G. Pilger, J. F. C. L. Costa and J. C. Koppe

Exact Conditioning to Linear Constraints in Kriging and Simulation

J. Gómez-Hernández, R. Froidevaux and P. Biver

A Dimension-reduction Approach for Spectral Tempering Using Empirical Orthogonal Functions

A. Pintore and C. C. Holmes

A New Model for Incorporating Spatial Association and Singularity in Interpolation of Exploratory Data

Q. Cheng

Lognormal Kriging: Bias Adjustment and Kriging Variances

N. Cressie and M. Pavliková

Evaluating Information Redundancy Through the Tau Model

S. Krishnan, A. Boucher and A. Journel

An Information Content Measure Using Multiple-point Statistics

Y. Liu

Internal Consistency and Inference of Change-of-support Isofactorial Models

X. Emery and J.M. Ortiz

History Matching Under Geological Control: Application to a North Sea

Reservoir

B. T. Hoffman and J. Caers

A Direct Sequential Simulation Approach to Streamline-Based History

Matching

J. Caers, H. Gross and A. R. Kovscek

Mapping Annual Nitrogen Dioxide Concentrations in Urban Areas

D. Gallois, C. de Fouquet, G. Le Loc'h, L. Malherbe and G. Cárdenas

A Step by Step Guide to Bi-Gaussian Disjunctive Kriging

J. Ortiz, B. Oz, and C.V. Deutsch. 
Assessing the Power of Zones of Abrupt Change Detection Test

E. Gabriel and D. Allard

Experimental Study of Multiple-support, Multiple-point Dependence and its Modeling

S. Krishnan

Validation of First-order Stochastic Theories on Reactive Solute Transport in Highly Stratified Aquifers

D. Fernàndez-Garcia and J.J. Gómez-Hernández

Geostatistical and Fourier Analysis Approaches in Mapping an Archeological

Site

A.T. Cavalheiro and J.M. Carvalho

BATGAM ${ }^{(\mathrm{C})}$ Geostatistical Software Based on GSLIB

B. Buxton, A. Pate, and M. Morara 


\section{FOREWORD}

The return of the congress to North America after 20 years of absence could not have been in a more ideal location. The beauty of Banff and the many offerings of the Rocky Mountains was the perfect background for a week of interesting and innovative discussions on the past, present and future of geostatistics.

The congress was well attended with approximately 200 delegates from 19 countries across six continents. There was a broad spectrum of students and seasoned geostatisticians who shared their knowledge in many areas of study including mining, petroleum, and environmental applications. You will find 119 papers in this two volume set. All papers were presented at the congress and have been peer-reviewed. They are grouped by the different sessions that were held in Banff and are in the order of presentation.

These papers provide a permanent record of different theoretical perspectives from the last four years. Not all of these ideas will stand the test of time and practice; however, their originality will endure. The practical applications in these proceedings provide nuggets of wisdom to those struggling to apply geostatistics in the best possible way. Students and practitioners will be digging through these papers for many years to come.

Oy Leuangthong Clayton V. Deutsch 


\title{
ACKNOWLEDGMENTS
}

We would like to thank the industry sponsors who contributed generously to the overall success and quality of the congress:

\author{
De Beers Canada \\ Earth Decision Sciences \\ Maptek Chile Ltda. \\ Mira Geoscience \\ Nexen Inc. \\ Petro-Canada \\ Placer Dome Inc. \\ Statios LLC \\ Total
}

We would also like to thank all the chair people, reviewers, volunteers, contributors and delegates who helped to make the congress a success. Special thanks to R. Mohan Srivastava for his help with the artwork. We thank the International Geostatistics committee for their comments and suggestions:

\author{
Winfred Assibey-Bonsu (South Africa) \\ Jef Caers (USA) \\ Clayton Deutsch (Canada) \\ Roussos Dimitrakopoulos (Australia) \\ Peter Dowd (Australia) \\ J. Jaime Gómez-Hernández (Spain) \\ Christian Lantuéjoul (France)
}

The staff and students of the Centre for Computational Geostatistics at the University of Alberta gave generously of their time to all aspects of organizing the congress. Amanda Potts (research administrator) provided essential administrative support. Sandra Correa, Paula Larrondo, Jason McLennan, Chad Neufeld, Weishan Ren, Stefan Zanon, and Linan Zhang (graduate students) provided invaluable assistance before and during the congress. 


\section{LIST OF PARTICIPANTS}

Abrahamsen, Petter, Norwegian Computing Center, Po Box 114 Blindern, Gaustadalleen 23, OSLO, NO0314, NORWAY

Alapetite, Julien, Earth Decision Science, 3 Route De Grenoble, MOIRANS, FR38430, FRANCE

Almeida, Jose, CIGA, Faculdade Ciencias Tecnologia, Universidade Nova Lisboa, MONTE DA CAPARICA, PORTUGAL

Arpat, Burc, Stanford University, Department of Petroleum Engineering, STANFORD, CA 94305, USA

Assibey- Bonsu, Winfred, Gold Fields Mining Services Ltd, 24 St. Andrews Rd, ZA 2193, SOUTH AFRICA

Assis Carlos, Luis, Anglo American Brasil Ltda, 502- Setor Santa Genoveva, Av. Interlandia, GOIANIA 74672-360, BRAZIL

Aug, Christophe, Centre de Geostatistique, 35 Rue Saint- Honore, Ecole Des Mines De Paris, FONTAINEBLEAU F77305, FRANCE

Bankes, Paul, Teck Cominco Limited, 600-200 Burrard Street, VANCOUVER, BC V6C 3L9, CANADA

Barbour, Russell, EPH/Yale School of Medicine, 60 College St. Rm 600, P. O. Box 208034, NEW HAVEN, CT 06520, USA

Barrera, Alvaro, University of Texas at Austin, 4900 E Oltorf St Apt 538, AUSTIN, TX 78741, USA

Bellentani, Giuseppe, ENI E\&P, Via Emilia 1-5 Pal., Uff.-5013 E, SAN DONATO MILANESE, 20097, ITALY

Berckmans, Arne, NIRAS, Kunstlaan 14, BRUSSSELS, 1210, BELGUIM

Bernard- Michel, Caroline, Ecole des Mines de Paris, 35 Rue Saint Honore FONTAINEBLEAU, F77305, FRANCE

Bertoli, Olivier, Quantitative Geoscience Pty Lt , Po Box 1304, FREMANTLE, 6959, AUSTRALIA 
Beucher, Helene, Ecole des Mines de Paris, 35 Rue Saint Honore, Centre De Geostatistique, FONTAINEBLEAU, F77305, FRANCE

Biver, Pierre, TOTAL SA, C S T J F, Ba 3112, Avenue Larribau, PAU, 64000, FRANCE

Blackney, Paul, Snowden Mining In. Consultants, P O Box 77, West Parth, 87 Colin St, W A 6872, PERTH, 6005, AUSTRALIA

Blaha, Petr, Holcim Group Support Ltd., Holderbank, HOLDERBANK, 5113, CHILE

Boucher, Alexandre, Stanford University, 151 Calderon Ave, Apt 232, MOUNTAIN VIEW, CA 94041, USA

Bourgault, Gilles, Computer Modelling Group Ltd, 351233 Street N W, Office \#200, CALGARY, AB T2L 2A6, CANADA

Brega, Fausto, ENI S.P.A- E\& P Division, Via Emilia, 1, San Donato Milanese, MILAN, 20097, ITALY

Brown, Gavin, De Beers Consolidated Mines, PO Box 350, CAPE TOWN, 8000, SOUTH AFRICA

Brown, Steven, Nexen Inc, 801-7th Avenue S W, CALGARY, AB T2P 3P7. CANADA

Buecker, Christian, R W E Dea A G, Ueberseering 40, HAMBURG, 22297, GERMANY

Bush, David, De Beers, P Bag X01 Southdale, Cnr. Crownwood Rd \& Diamond Dr, JOHANNESBURG, ZA2135, SOUTH AFRICA

Buxton, Bruce, Battelle Memorial Institute, 505 King Avenue, COLUMBUS, OH, 43201, USA

Caers, Jef, Stanford University, Petroleum Engineering, 367 Panama St, STANFORD, CA, 94305, USA

Carvalho, Jorge, Dep. Minas, Faculty Of Engineering, PORTO, 4200-465, PORTUGAL

Castro, Scarlet, Stanford University, 361 Green Earth Sciences Bldg., 367 Panama Street, STANFORD, CA, 94305, USA

Caumon, Guillaume, Stanford University, 367 Panama St., Petroleum Engineering Dept, STANFORD, CA, 94305, USA

Chappell, Adrian, University of Salford, Environment \& Life Sciences, Peel Building, The Crescent, SALFORD, M5 4WT, UK 
Chelak, Robert, Roxar Canada, 1200 815-8 Th Ave SW, CALGARY, AB, T2P 3P2, CANADA

Chen, Zhuoheng, Geological Survey of Canada, 3303-33rd Street N.W., CALGARY, $\mathrm{AB}, \mathrm{T} 2 \mathrm{~L}$ 2A7, CANADA

Cheng, Qiuming, York University, 4700 Keele Street, NORTH YORK, ON, M3J 1P3, CANADA

Chiles, Jean- Paul, Ecole des Mines de Paris, 35 Rue Saint Honore, Centre De Geostatistique, FONTAINEBLEAU, FR77305, FRANCE

Coburn, Timothy, Abilene Christian University, Acu Box 29315, ABILENE, TX, 79699, USA

Cornah, Alastair, University of Exeter, Camborne School Of Mines, Trevenson Rd, CORNWALL, TR15 3SE, UK

Correa Montero, Sandra, University of Alberta, Department of Civil \& Environmental. Engineering, 3-133 Markin/CNRL Natural Resources Engineering Facility, EDMONTON, AB, T6G 2W2, CANADA

Costa, Joao Felipe, UFRGS, Av. Osvaldo Aranha 99/504, PORTO ALEGRE, 90035190, BRAZIL

Costa, Marcelo, BRAZIL

Da Silva, Emidio, University A. Neto, Faculdade De Engenharis-d De, Eng. Minas Av. 21 De Janeiro, LUANDA, 1756, ANGOLA

Dagbert, Michel, Geostat Systems Int. Inc, 10 Blvd Seigneurie E, Suite 203, BLAINVILLE, QC, J7C 3V5, CANADA

Dahle, Pal, Norwegian Computing Center, P O Box 114, Blindern, Gaustadalleen 23, OSLO, NO0314, NORWAY

Daly, Colin, Roxar Ltd, Pinnacle House, 17-25 Hartfield Rd, WIMBLEDON, SW19 3SE, UK

De Visser, Jan, RSG Global

Della Rossa, Ernesto, ENI S.P.A, Eni E\& P- Apsi, Via Emilia 1, San Donato Milanese, MILANO, 20097, ITALY

Deutsch, Clayton, University of Alberta, Department. of Civil \& Environmental Engineering, 3-133 Markin/CNRL Natural Resources Engineering Facility, EDMONTON, AB, T6G 2W2, CANADA 
Dimitrakopoulos, Roussos, University of Queensland, Wh Bryan Mining Geo. Res. Cen, Richards Building, BRISBANE, 4072, AUSTRALIA

Dohm, Christina, Anglo Operations Ltd., P O Box 61587, MARSHALLTOWN, 2107, JOHANNESBURG, 2000, SOUTH AFRICA

Dose, Thies, RWE Dea AG, Ueberseering 40, Hamburg, HAMBURG, D22297, GERMANY

Dowd, Peter, Faculty of Engineering, Computer and Mathematical Sciences, University of Adelaide, ADELAIDE, SA 5005, AUSTRALIA

Dube, Pascal, Cameco, 243 Beckett Green, SASKATOON, SK S7N 4W1, CANADA

Duggan, Sean, De Beers Consolidated Mines, 117 Hertzog Boulevard, CAPE TOWN, 8001, SOUTH AFRICA

Dungan, Jennifer, NASA Ames Research Center

Eidsvik, Jo, Statoil, Ark Ebbels V 10, Statoil Research Center, TRONDHEIM, NO7032, NORWAY

Emery, Xavier, University of Chile, Dept. Of Mining Engineering, Avenida Tupper 2069, SANTIAGO, 8320000, CHILE

Faechner, Ty, Assiniboine Community College, 1430 Victoria Ave East, BRANDON, MB, R7A 2A9, CANADA

Fisher, Thomas, Colorado School of Mines, 1211-6th Street, GOLDEN, CO, 80403, USA

Francois Bongarcon, Dominique, Agoratek International, 345 Stanford Center Pmb\# 432, PALO ALTO, CA, 94304, USA

Froidevaux, Roland, FSS Consultants SA, 9, Rue Boissonnas, GENEVA, 1256, SWITZERLAND

Frykman, Peter, Geological Suvery of Denmark, G E U S, Oster Voldgade 10, COPENHAGEN, 1350, DENMARK

Gabriel, Edith, INRA, Domaine St Paul, Site Agropic, AVIGNON, 84914, FRANCE

Gallagher Jr., Joseph, ConocoPhillips, Reservoir Sciences, 269 Geoscience Bldg, BARTLESVILLE, OK, 74004, USA

Garcia, Michel, FSS International, 1956, Avenue Roger Salengro, CHAVILLE, FR92370, FRANCE 
Garner, David, Conoco Phillips Canada Ltd., P.o. Box 130, 401-9th Ave S W, CALGARY, AB, T2P 2H7, CANADA

Glacken, Ian, Snowden Mining In. Consultants, P O Box 77 West Perth, 87 Colin St, WA 6872, PERTH, 6005, AUSTRALIA

Gloaguen, Erwan, Ecole Polytechnique, C. P. 6079 Succ. Centre-ville, MONTREAL, QC, H3C 3A7, CANADA

Gomez- Hernandez, Jaime, Univ. Politecnica de Valencia, Escuela De Ing. De Caminos, Camino De Vera S/n, VALENCIA, EP46022, SPAIN

Gonzalez, Eric, Maptek South America, 5 Norte 112, Vina Del Mar, VINA DEL MAR, 2520180, CHILE

Goovaerts, Pierre, BioMedware, 516 N State St, ANN ARBOR, MI, 48104, USA

Gray, James, Teck Cominco Ltd, 600-200 Burrard St, VANCOUVER, BC, V6C 3L9, CANADA

Grills, John Andrew, De Beers Consolidated Mines, 117 Hertzog Boulevard, PO Box 350, CAPE TOWN, 8000, SOUTH AFRICA

Gringarten, Emmanuel, Earth Decision Sciences, 11011 Richmond Ave, Suite 350, HOUSTON, TX, 77042, USA

Guenard, Cindy, Talisman Energy Inc., Suite 3400, 888-3rd Street S.W., CALGARY, AB, T2P 5C5, CANADA

Guibal, Daniel, SRK Consulting, P. O. Box 943 West Perth, 1064 Hay Street, WEST PERTH, 6005, AUSTRALIA

Harding, Andrew, Chevron Texaco, 6001 Bollinger Canyon Road, DANVILLE, CA, 94506, USA

Hauge, Ragnar, Norwegian Computing Center, P. O. Box 114 Blindern, OsLO, 0314, NORWAY

Hayes, Sean, Talisman Energy Inc., Suite 3400, 888-3rd Street S W, CALGARY, AB, T2P 5C5, CANADA

Henry, Emmanuel, AMEC/Ecole Polytechnique, De Montreal, Suite 700, 2020 Winston Park Dr, OAKVILLE, ON, L6H 6X7, CANADA

Hlavka, Christine, NASA, N A S A/ A M E S Res. Center, Mail Stop 242-4, MOFFETT FIELD, CA, 94035, USA 
Hoffman, Todd, Stanford University, 367 Panama Street, Green Earth Sciences Bldg., STANFORD, CA 94305, USA

Hu, Lin Ying, I F P, 14 A. De Bois Preau, RUEIL- MALMAISON, 92870, FRANCE

Huysmans, Marijke, University of Leuven, Redingenstraat 16, LEUVEN, 3000, BELGIUM

Isaaks, Edward, Isaaks \& Co., 1042 Wilmington Way, REDWOOD CITY, CA, 94062, USA

Jackson, Scott, Quantitative Geoscience Pty Lt, P O Box 1304, FREMANTLE, 6959, AUSTRALIA

Jaquet, Olivier, Colenco Power Engineering Ltd, Taefernstrasse 26, BADEN, 5405, CHILE

John, Abraham, University of Texas at Austin, Cpe 2.502, Department of Petroleum \& Geosystems, AUSTIN, TX, 78712, USA

Journel, Andre, Stanford University, Petroleum Engineering Department., STANFORD, CA, 94305, USA

Jutras, Marc, Placer Dome Inc, P. O. Box 49330 Bentall Sa., Suite 1600-1055 Dunsmir St., VANCOUVER, BC, V7X 1P1, CANADA

Kashib, Tarun, EnCana Corporation, 150, 9th Avenue S.W, .P O Box 2850, CALGARY, $\mathrm{AB}, \mathrm{T} 2 \mathrm{P}$ 2S5, CANADA

Keech, Christopher, Placer Dome Inc, P O Box 49330 Bentall Station, 1600-1055

Dunsmuir St, VANCOUVER, BC, V7X 1P1, CANADA

Khan, Dan, 1601, 8708 - 106th Street, EDMONTON, AB, T6E 4J5, CANADA

Kolbjornsen, Odd, Norwegian Computing Center, P.O. Box 114 Blindern, OSLO, 0314 NORWAY

Koppe, Jair, Univ. of Rio Grande do Sul, Av Cavalhada 5205 Casa 32, PORTO

ALEGRE, 91.751-831, BRASIL

Krige, Daniel G, Po Box 121, FLORIDA HILLS, 1716, SOUTH AFRICA

Krishnan, Sunderrajan, Stanford University, \#353 Green Earth Sciences, Geological \& Environmental Sci, STANFORD, CA, 94305, USA

Kyriakidis, Phaedon, University of California, Dept. of Geography, Ellison Hall 5710, SANTA BARABRA, CA, 93106, USA 
Larrondo, Paula, University of Alberta, Department of Civil \& Environmental Engineering, 3-133 Markin/CNRL Natural Resources Engineering Facility, EDMONTON, AB, T6G 2W2, CANADA

Le Loc`h, Gaelle, Ecole des Mines de Paris, 35 Rue Saint Honore, Centre De Geostatistique, FONTAINEBLEAU, F77305, FRANCE

Le Ravalec, Mickaela, I F P, 14 A. Bois Preau, Rueil-malmaison., 92852, FRANCE

Leuangthong, Oy, University of Alberta, Department of Civil \& Environmental Engineering, 3-133 Markin/CNRL Natural Resources Engineering Facility, EDMONTON, AB, T6G 2W2, CANADA

Lewis, Richard, Placer Dome Asia Pacific Ltd., G P O Box 465, Brisbane, 4001, 90 Alison Road, RANWICK, AU 2031, AUSTRALIA

Liu, Yuhong, ExxonMobil Upstream Research, P. O. Box 2189, HOUSTON, TX, 77252, USA

Lodoen, Ole Petter, Norwegian Univ. of Science \& T, Dept. Of Mathematical Sciences, TRONDHEIM, N-7491, NORWAY

Maharaja, Amisha, Stanford University, 51 Dudley Lane, Apt 424, STANFORD, CA, 94305, USA

Marcotte, Denis, Ecole Polytechnique, C. P. 6079 Succ. Centre-ville, SAINT-BRUNO, QC, J3V 4J7, CANADA

Mattison, Blair, Petro- Canada, 150-6th Ave. SW, CALGARY, AB, T2P 3E3, CANADA

Maunula, Tim, Wardrop Engineering, 2042 Merchants Gate, OAKVILLE, ON, L6M 2Z8, CANADA

Mc Kenna, Sean, Sandia National Laboratories, P O Box 5800 M S 0735, ALBUQUERQUE, NM, 87185, USA

Mc Lennan, Jason, University of Alberta, Dept. Of Civil \& Environmental. Engineering., 3-133 Markin/CNRL Natural Resources Engineering Facility, EDMONTON, AB, T6G 2W2, CANADA

Meddaugh, William, ChevronTexaco Energy Tech. Co., 4800 Fournace Place, P O Box 430, BELLAIRE, TX, 77401, USA

Merchan, Sergio, Encana, 421-7th Avenue SW, Calgary, AB, T2P 4K9, CANADA

Monestiez, Pascal, INRA, Domaine St Paul Site Agropic, Avignon, AVIGNON, 84914, FRANCE 
Murphy, Mark, Snowden Mining Ind. Consultant, P O Box 77, West Perth,, 87 Colin St, WA, 6872, PERTH, 6005, AUSTRALIA

Myers, Donald, University of Arizona, Dept. Of Mathematics, 617 North Santa Rita, TUCSON, AZ, 85721, USA

Naveau, Philippe, University of Colorado, Applied Mathematics Dept., 526 U C B, BOULDER, CO, 80309, USA

Nel, Stefanus, De Beers Consolidated Mines, Private Bag 1, Southdale, Gauteng, ZA 2135, SOUTH AFRICA

Neufeld, Chad, University of Alberta, Department. Of Civil \& Environment Engineering, 3-133 Markin/CNRL Natural Resources Engineering Facility, EDMONTON, AB, T6G 2W2, CANADA

Nicholas, Grant D., De Beers, The Dtc, Mendip Court, Bath Rd, South Horrington, WELLS, BA5 3DG, UK

Norrena, Karl, Nexen Canada Ltd, 801-7th Ave SW, CALGARY, AB, T2P 3P7, CANADA

Norris, Brett, Paramount Energy Trust, 500, 630-4th Ave SW, CALGARY, AB, T2P 0L9, CANADA

Nowak, Marek, Nowak Consultants Inc., 1307 Brunette Ave, COQUITLAM, BC, V3K 1G6, CANADA

Okabe, Hiroshi, Imperial College London, Japan Oil, Gas \& Metals Nat.co, 1-2-2

Hamada, Mihama-ku, CHIBA- SHI, 261-0025, JAPAN

Ortiz Cabrera, Julian, Universidad de Chile, Av. Tupper 2069, SANTIAGO, 837-0451, CHILE

Osburn, William, St John River Water Management, 4049 Reid St., P O Box 1429, PALATKA, FL, 32178, USA

Parker, Harry, AMEC Inc, 19083 Santa Maria Ave, CASTRO VALLEY, CA, 94546, USA

Perron, Gervais, Mira Geoscience Ltd, 310 Victoria Avenue, Suite 309, WESTMOUNT, QC, H3Z 2M9, CANADA

Pilger, Gustavo, Federal Univ of Rio Grande do, Av. Osvaldo Aranha 99/504, PORTO ALEGRE, 90035-190, BRAZIL

Pintore, Alexandre, Imperial College of London, 11 Walton Well Road, OXFORD, OX2 6ED, UK 
Pontiggia, Marco, ENI E\&P, Via Emilia 1-5 Pal., Uff.-5013 E, SAN DONATO MILANESE, 20097, ITALY

Porjesz, Robert, CGG, Casa Bote B, Casa 332, LECHERIA, VENEZULA

Potts, Amanda, University of Alberta, Department of Civil \& Environmental Engineering, 3-133 Markin/CNRL Natural Resources Engineering Facility, EDMONTON, AB, T6G 2W2, CANADA

Prins, Chris, The DTC, Mendip Court, Bath Road, Minrad, Wells, SOMERSET, BA5 3DG, UK

Pyrcz, Michael, University of Alberta, Dept. Of Civil \& Environmental Engineering, 3133 Markin/CNRL Natural Resources Engineering Facility, EDMONTON, AB, T6G 2W2, CANADA

Remy, Nicolas, Standford University, G E S Department, Braun Hall, STANFORD, CA, 94305, USA

Ren, Weishan, University of Alberta, Dept. Of Civil \& Environmental Engineering, 3-133 Markin/CNRL Natural Resources Engineering Facility, EDMONTON, AB, T6G 2W2, CANADA

Riddell, Marla, EnCana, \#21, 18-20 Hillcrest Road, LONDON, W5 1HJ, UK

Rivoirard, Jacques, Ecole des Mines de Paris, Centre De Gostatistique, 35 Rue SaintHonore, FONTAINEBLEAU, 77210, FRANCE

Russo, Ana, CMRP/ IST, Av. Rovisco Pais, 1, Lisboa, 1049-001. PORTUGAL

Saito, Hirotaka, Sandia National Lab., P O Box 5800 M S 0735, ALBUQUERQUE, NM, 87185 , USA

Saldanha, Paulo, 4 Dom Thomas Murphy St., WY, BRAZIL

Samal, Abani, Southern Illinois University, 2000 Evergreen Terrace Dr. W., Apt 07, CARBONDALE, IL, 62901, USA

Savoie, Luc, Candian Natural Resources Ltd, 2500, 855-2nd St SW, CALGARY, AB, T2P 4J8, CANADA

Schirmer, Patrice, TOTAL, 2 Place Coupole, La Defense, PARIS, .092604, FRANCE

Schnetzler, Emmanuel, Statios, 1345 Rhode Island Street, SAN FRANCISCO, CA, 94107, USA

Schofield, Neil, Hellman \& Schofield Pty. Ltd, P. O. Box 599, Beecroft, Nsw, 2119 , Suite 6, 3 Trelawney St, EASTWOOD, 2122, AUSTRALIA 
Scott, Anthony, Placer Dome, P O Box 49330 Bentall Station, Suite 1600-1055

Dunsmuir St., VANCOUVER, BC, V6G 3J3, CANADA

Seibel, Gordon, AngloGold, P O Box 191, VICTOR, CO, 80860, USA

Shi, Genbao, Landmark Graphics, Two Barton Skyway, 1601 S. Mopac Expressway, AUSTIN, TX, 78746, USA

Skorstad, Arnem Norwegian Computing Center, P O Box 114 Blindern, Gaustadalleen 23, OSLO, NO0314, NORWAY

Soares, Amilcar, CMRP/ IST, Av. Rovisco Pais, 1, LISBOA, 1049-001, PORTUGAL

Soulie, Michel, Ecole Polytechnique, P. O. Box 6079, Station Centre-ville, MONTREAL, QC, H3C 3A7, CANADA

Srinivasan, Sanjay, University of Texas at Austin, Petroleum \& Geosystems Eng., 1 University Station C0300, AUSTIN, TX, 78712, USA

Srivastava, Mohan, FSS Canada, 42 Morton Road, TORONTO, ON, M4C 4N8, CANADA

Stavropoulos, Achilles, Canadian Natural Resources Ltd, 900, 311-6th Ave. SW, CALGARY, AB, T2P 3H2, CANADA

Stephenson, John, Imperial College, Dept. Of Earth Science \& Eng, Royal School Of Mines, LONDON, SW7 2AZ, UK

Strebelle, Sebastien, ChevronTexaco ETC, 6001 Bollinger Canyon Rd,, Room D1200, SAN RAMON, CA, 94583, USA

Suzuki, Satomi, Stanford University, 367 Panama St., STANFORD, CA, 94305, USA

Syversveen, Anne Randi, Norwegian Computing Center, P O Box 411 Blindern, OSLO, 0314, NORWAY

Thurston, Malcolm, De Beers Canada, 65 Overlea Blvd, Suite 400, TORONTO, ON, M4H 1P1, CANADA

Tjelmeland, Haakon, Norwegian University, Of Science \& Technology, Dept. Of Mathematical Sciences, TRONDHEIM, 7491, NORWAY

Tolmay, Leon, Gold Fields, 4 Cedar Avenue, WESTONARIA, 1779, SOUTH AFRICA

Toscano, Claudio, ENI S.P.A -E \& P Division, Via Emilia 1, San Donato Milanese, MILAN, 1-20097, ITALY 
Tran, Thomas, Chevron Texaco, 1546 China Grade Loop, Room A7, BAKERSFIELD, CA, 93308, USA

Tureyen, Omer Inanc, Stanford University, 367 Panama St., 065 Green Earth Sciences Bldg., STANFORD, CA, 94305, USA

Vann, John, Quantitative Geoscience Pty Lt, P O Box 1304, FREMANTLE, 6959, AUSTRALIA

Vasquez, Christina, XU Power, 3010 State St. \#309, DALLAS, TX, 75204, USA

Verly, Georges, Placer Dome, P. O. Box 49330, Bentall Station, VANCOUVER, BC, V7X 1P1, CANADA

Voelker, Joe, Stanford University, P O Box 12864, STANFORD, CA, 94309, USA

Wackernagel, Hans, Ecole des Mines De Paris, 35 Rue Saint Honore, Centre De Geostatistique, FONTAINEBLEAU, F-77305, FRANCE

Wagner, Jayne, De Beers, Private Bag X01, Southdale, 2135 Cornerstone Bldg., JOHANNESBURG, 2135, SOUTH AFRICA

Wain, Anthony, Talisman Energy Inc., 888-3rd Street SW, Suite 3400, CALGARY, AB, T2P 5C5, CANADA

Walls, Elizabeth, Petro-Canada, 208, 930 18th Ave SW, CALGARY, AB, T2T 0H1, CANADA

Watson, Michael, Husky Energy, Box 6525, Station D, 707 8th Ave. S W, CALGARY, $\mathrm{AB}, \mathrm{T} 2 \mathrm{P}$ 3G7, CANADA

Wawruch, Tomasz, Anglo American Chile, Mailbox 16178, Correo 9, 291 Pedro De Valdivia Ave, SANTIAGO, 6640594, CHILE

Wen, Xian- Huan, Chevron Texaco ETC, 6001 Bollinger Canyon Road, D2092, SAN RAMON, CA, 94583, USA

Wu, Jianbing, SCRF, Stanford University, Petroleum Engineering Dept, 367 Panama Street, STANFORD, CA, 94305, USA

Yao, Tingting, ExxonMobil., Upstream Research Company, P. O. Box 2189, S W 508, HOUSTON, TX, 77252, USA

Yarus, Jeffrey, Quantitative Geosciences, LLP, 2900 Wilcrest Suite 370, HOUSTON, TX, 77042, USA 
Zanon, Stefan, University of Alberta, Dept. Of Civil \& Environmental Engineering, 3-133 Markin/CNRL Natural Resources Engineering Facility, EDMONTON, AB, T6G 2W2, CANADA

Zhang, Linan, University of Alberta, Dept. Of Civil \& Environmental Engineering, 3-133 Markin/CNRL Natural Resources Engineering Facility, EDMONTON, AB, T6G 2W2, CANADA

Zhang, Tuanfeng, Stanford University, 113 A, E. V, STANFORD, CA, 94305, USA 